\title{
Impact of A1/A2 Milk on Health: Facts and Implications
}

\author{
Thirupathy Venkatachlapathy R*, Pramod S, Lasna Shabib and Bibin Beecha \\ Kerala Veterinary and Animal Sciences University, Livestock Research Station, India
}

Submission: December 14, 2018; Published: January 23, 2019

*Corresponding author: Thirupathy Venkatachlapathy R, Kerala Veterinary and Animal Sciences University, Livestock Research Station, Thiruvazhamkunnu, Palakkad, Kerala -678601, India

\section{Abstract}

A single nucleotide polymorphism (Cytosine to Adenine) at codon 67 of $\beta$ - Casein gene generated A1 and A2 isoforms of $\beta$ - Casein. The protein A1 $\beta$ - Casein is known to release Beta Casomorphins (BCM's), which are peptides containing 4 to 11 amino acids upon digestion in gastro intestinal tract. BCM's were observed to be associated with non-communicable diseases like type I diabetes, coronary heart disease (HD), schizophrenia and autism. Of late, evidence surfaced after experiments in animal models which suggested that BCM's had beneficial effects also.

Abbreviations: BCM's: Beta Casomorphins; HD: Heart Disease; CSN2: Bovine $\beta$ - Casein; GIT: Gastro Intestinal Tract; PepX: X-Prolyldipeptidyl Aminopeptidase

\section{Introduction}

Milk is regarded as a complete food which provides energy, protein, vitamin B12 and minerals such as calcium, magnesium and phosphorus [1]. Milk of bovines typically contains about $15 \%$ of solids dispersed in an aqueous medium. Caseins and whey proteins account for $80 \%$ of milk protein. $\beta$ - Casein, with 209 amino acids is the second most abundant protein in cow's milk, constituting about $30 \%$ of its total protein [2]. Bovine $\beta$ - Casein (CSN2) gene is located on $6^{\text {th }}$ chromosome in a cluster of four genes viz. alpha s1, alpha s2, beta and kappa. Mutations resulted in the formation of twelve genetic variants of CSN2 gene which were A1, A2, A3, B, C, D, E, F, H1, H2, I and G. Among these, A1, A2 and $B$ variants are commonly observed in cattle populations $[3,4]$. The $\mathrm{A} 1$ and $\mathrm{A} 2$ isoforms differ with respect to position 67 , where the variant $A 1 \beta$-Casein has amino acid histidine and $A 2 \beta$ - Casein has proline. The difference is attributed to a single nucleotide polymorphism at codon 67 of $\beta$ - Casein gene [5] wherein CCT (codes proline in A2 $\beta$ - Casein) changed to CAT (codes histidine in $A 1 \beta$-Casein). Digestion of A1 $\beta$ - Casein by proteolytic enzymes like pepsin, elastase etc. releases a seven-amino-acid peptide, betacasomorphin-7 (BCM-7), by virtue of the presence of histidine at positon 67 , while $A 2 \beta$ - Casein with proline at position 67 does not release BCM-7. Beta-Casomorphins (BCM's) are 4 to 11 amino acid peptides derived from enzymatic splitting of larger proteins inside biological systems or in vitro conditions. Absorption and transport of BCM's across the intestinal epithelial cells have been confirmed by in-vivo and in-vitro models $[6,7]$.

\section{Evolution of A1 and A2 genes}

The ancestors of modern cattle were thought to have produced A2 type of casein. A natural mutation in $\beta$ - Casein gene of Holstein cattle about 8,000 years ago culminated in the origin of A1 variant. A cow could inherit two copies of the gene, one each from its sire and dam. Therefore, genotypes of A2A2 (homozygous), A1A2 (heterozygous) or A1A1 (homozygous) are possible in this locus. Being co-dominant, cattle with $\mathrm{A} 1 \mathrm{~A} 2$ genotype secretes both types of Casein in milk [2]. European breeds like Holstein Friesian, Ayrshire and Brown Swiss had higher frequency of A1 alleles ranging from 0.10 to 0.72 . Reports from Holstein Friesian breed indicate that frequency of A1 alleles varied between 0.31 to 0.66 [8]. A1 alleles were absent in most Indian breeds of cattle and buffaloes except for Malanad Gidda and Kherigarh which hosted the allele in frequencies around 0.1 [9].

\section{Biological effects of Beta-Casomorphins (BCM's)}

Proteins from various sources like milk, animals, fish, plants and bacteria have peptide sequences which possess biological activity. These peptides have 2 to 50 amino acid residues and maybe released subsequent to food processing or digestion in gastro intestinal tract (GIT). Effects like hypotension, immune modulation, etc. including opioid receptor agonism and antagosnism were attributed to some of them. BCM's interact with opioid receptors in the body and bring about physiological effects. Opioid peptides can be formed even from blood proteins, including albumin, $\gamma$-globulins and haemoglobin [10].

\section{BCM7 in Dairy Products}

The concentration of BCM7 in raw milk varied with genotype of cattle in the order $\mathrm{A} 2 \mathrm{~A} 2<\mathrm{A} 1 \mathrm{~A} 2<\mathrm{A} 1 \mathrm{~A} 1$ [11]. The formation of $\mathrm{BCM}$ in fermented products using Lactic acid bacillus cultures maybe limited due to the activity of bacterial enzyme X-prolyldipeptidyl 
aminopeptidase (PepX). The enzyme acted on peptide bonds between proline and other amino acids, thereby degrading BCM's [12]. Conflicting report by Kunda [13] suggested that peptides containing BCM7 sequence was identified in yoghurt, a fermented dairy product. BCM7 was also not detected in several cheese varieties including Cheddar and Swiss cheese [10].

\section{Impact of BCM's on Health}

BCM-7 was identified to interact with opioid receptor ' $\mu$ ' located in the central nervous system, GIT, immune cells etc. and was hypothesised to be a risk factor for type I diabetes, coronary heart disease (HD), schizophrenia and autism [14,15] in humans. BCM's may delay psychomotor development in babies [16] and could be a risk factor which trigger Sudden Infant Death Syndrome [17]. Besides, reports suggest that BCM's may suppress cellular immunity [18] and cause milk allergy [19]. Researchers world over were concerned with the problem as significant number of European cattle were carriers of A1 Casein gene. Health benefits attributed to BCM-7 were also observed by researchers working with rat models. It was identified that BCM-7 protected human lens epithelial cells and pancreatic cells [20] from oxidative damage [21]. BCM-7 was observed to inhibit myocardial damage associated with diabetic cardio myopathy [22]. The peptide was found to have protective effects in diabetic nephropathy [23].

\section{Conclusion}

The European Food Safety Agency critically analysed available literature and ruled out involvement of BCM's in the pathogenesis of cardio vascular diseases, type- I diabetes mellitus or SIDS [10]. Fermented milk products (due to break down of BCM's) and milk/ milk products prepared from desi cattle or buffaloes (due to low frequency of A1 Casein gene) may be regarded as safe. Several reviews were published in relation with BCM's which evaluate formation and degradation [24], health effects [2,25], gastro intestinal effects [26], physiological effects of BCM's [27,28], etc. among others. Analysis of available literature indicates that though there is epidemiological evidence to support ill effects of BCM's, conclusive evidence is not available. Evidence supporting positive effects of BCM's also emerged from experiments conducted in rat models, which further interfere with our ability to draw inferences. Controversies involving A1 and A2 milk are therefore far from over.

\begin{tabular}{l} 
Your next submission with Juniper Publishers \\
will reach you the below assets \\
- Quality Editorial service \\
- Swift Peer Review \\
- Reprints availability \\
- E-prints Service \\
- Manuscript Podcast for convenient understanding \\
- Global attainment for your research \\
- Manuscript accessibility in different formats \\
( Pdf, E-pub, Full Text, Audio) \\
- Unceasing customer service \\
Track the below URL for one-step submission \\
https://juniperpublishers.com/online-submission.php \\
\hline
\end{tabular}

